IZADP No. 2361

The Effects of Rent-Sharing on the Gender Wage Gap in the Israeli Manufacturing Sector

Guy Navon

Ilan Tojerow

October 2006 


\title{
The Effects of Rent-Sharing on the Gender Wage Gap in the Israeli Manufacturing Sector
}

\author{
Guy Navon \\ Bank of Israel \\ Ilan Tojerow \\ Free University of Brussels (DULBEA) \\ and IZA Bonn
}

Discussion Paper No. 2361

October 2006

\author{
IZA \\ P.O. Box 7240 \\ 53072 Bonn \\ Germany \\ Phone: +49-228-3894-0 \\ Fax: +49-228-3894-180 \\ E-mail: iza@iza.org
}

\begin{abstract}
Any opinions expressed here are those of the author(s) and not those of the institute. Research disseminated by IZA may include views on policy, but the institute itself takes no institutional policy positions.

The Institute for the Study of Labor (IZA) in Bonn is a local and virtual international research center and a place of communication between science, politics and business. IZA is an independent nonprofit company supported by Deutsche Post World Net. The center is associated with the University of Bonn and offers a stimulating research environment through its research networks, research support, and visitors and doctoral programs. IZA engages in (i) original and internationally competitive research in all fields of labor economics, (ii) development of policy concepts, and (iii) dissemination of research results and concepts to the interested public.
\end{abstract}

IZA Discussion Papers often represent preliminary work and are circulated to encourage discussion. Citation of such a paper should account for its provisional character. A revised version may be available directly from the author. 


\section{ABSTRACT \\ The Effects of Rent-Sharing on the Gender Wage Gap in the Israeli Manufacturing Sector ${ }^{*}$}

This paper analyzes the impact of workplace characteristics on individual wages based on a unique cross-section matched employer-employee dataset for the Israeli private manufacturing sector in 1995; especially, we examine the effects of the interaction between rent-sharing and wages on the gender wage gap. The empirical findings show that individual compensation is significantly and positively related to firms' profits-per-employee even when controlling for group effects in the residuals, individual and firms' characteristics, industry wage differentials and endogeneity of profits. Wage-profit elasticity is found to be 14 percent and it is insignificantly different between genders. With respect to the overall gender wage gap (on average women earn 28 percent less than men), the results show that within firms there is no gender discrimination and that 12 percent of this gap can be explained by the wage-profits profile and by the fact that women are more likely to be employed in less profitable firms than men.

JEL Classification: D31, J16, J31, J70

Keywords: $\quad$ wages, profits, rent sharing, gender

Corresponding author:

Ilan Tojerow

DULBEA, CP140

Université Libre de Bruxelles

50, Av. F.D. Roosevelt

B-1050 Brussels

Belgium

E-mail: itojerow@ulb.ac.be

* Any views expressed in this paper are those of the authors and do not necessarily reflect those of the Bank of Israel. 


\section{Introduction}

This paper analyzes how rent-sharing interacts with the gender wage gap in the Israeli private manufacturing sector. In this sense, rent-sharing is defined as the employee compensation above her marginal productivity. To perform the analysis, we first investigate how individual gross hourly wages are related to firms' profits-per-employee, using individual and firms' characteristics as control variables. Secondly, we examine whether these results vary for men and women. Finally, we analyze, on the basis of Oaxaca's (1973) and Blinder's (1973) decomposition technique, what proportion of the overall gender wage gap can be attributed to the gender differences in mean profit levels of employing firms, and what proportion to the differences between wage-profit elasticities for men and women.

The debate on the gender wage has been ongoing since Becker's (1957) seminal paper. Focusing on the relationship between labor market segregation and the gender wage gap, several studies show that a large portion of the gender wage gap is due to the concentration of women in lower-paying occupations or industries. Others suggest that a substantial part of the gap is due to gender discrimination against women (Bayard et al, 1999). We do not intend to answer the question why women earn less than men, but to answer what is the role of rentsharing in the gender wage-gap.

The empirical debate on the causes of earning inequalities was reopened at the end of the 1980s by Krueger and Summers (1988) who highlighted the fact that the wages structure in the US was not compatible with a competitive framework, according to which wage differentials in equilibrium are explained either through differences in the quality of the labor force - measured in terms of productive capacity - or by so-called compensating differences. Some authors (Hartog et al., 1997) believe that the justification put forward by Holmlund and Zetterberg (1991), based upon the rent-sharing theory, is compelling. The latter showed that the influence of variations in prices and productivity on wages is strong in the US, moderate in Germany and low in the Scandinavian countries. The elasticity between the sectoral environment and wages would thus be more pronounced in non-corporatist countries. i.e., the determination of wages would depend more on the general macro-economic conditions in the corporatist countries. This result might be explained by the fact that the explicit or implicit co-ordination of wage bargaining in corporatist countries restricts the insider power of the workers - their ability to 
capture part of the sectoral rents. In addition, it is argued that the policy of 'wage solidarity' pursued by labor unions in most of the corporatist countries reinforces this phenomenon. For instance, Vainiomäki and Laaksonen (1995, p. 172) emphasize that "the difference (in the dispersion of inter-industry wage differentials) between Sweden and Finland (may derive from) the less successful implementation of solidarity wage policy and more flexibility in industry level agreements in Finland.” This strand of the literature suggests that rent-sharing is partly responsible for the observed sectoral wage premium and for their apparently higher dispersion in non-corporatist countries. Martins (2004) and Kramarz (2003) raised the problem of potential biases from estimating the rent-sharing: even after controlling for the endogeneity of profits, wages and unemployment, there is a potential bias caused by the correlation between profits and missing unobserved variables that capture the employee's 'ability' (or skills). To eliminate this bias, they suggest using instrumental variables to uncover the exogenous variability of profits and to identify the rent-sharing effect.

The question is whether Israeli firms share rents with their employees, as in other countries. The bargaining framework may apply in European countries, where collective bargaining power is high, but may cause potential bias in countries like Israel where the bargaining power of trade union members is relatively low. ${ }^{1}$ Empirical findings reported in the paper show that individual gross hourly wages are significantly and positively related to firms' profits-peremployee even when controlling for group effects in the residuals, individual and firm characteristics, industry wage differentials and endogeneity of profits. Our instrumented wageprofit elasticity is of a magnitude of 0.15 and it is significantly different for men and women. Regarding the overall gender wage gap (on average women earn 30.8 percent less than men), our results show that around 12 percent of the gap can be explained by the fact that on average women are employed in firms where profits-per-employee are lower. Thus, these findings suggest that a substantial part of the gender wage gap is attributable to the concentration of women in less profitable firms.

PT ${ }^{1}$ TPAccording to "World Labor Report 1997-98: Industrial Relations, Democracy and Social Stability," International Labor Organization (1997). The collective bargaining power is measured by the proportion of employees under collective agreements and the union level density. 
The paper consists of 6 sections: The following section presents previous empirical findings; Section 3 presents the theoretical model; Sections 4 and 5 describe the data set and the empirical findings, and Section 6 concludes our findings.

\section{Literature Review}

The theoretical approach in the literature of rent-sharing and wages is a bargaining framework the right-to-manage or the efficient bargaining model, in which insiders - not necessarily a labor union - bargain over wages and eventually employment. ${ }^{2}$ Findings from this literature, which essentially concentrated in European countries, show that profitable firms pay higher wages than non-profitable firms even when controlling for human capital characteristics and firmfixed-effects. For Britain, Canada and the US, the estimated elasticities between wages and profits-per-employee range between 0.04 and 0.2 , depending on the quality of instruments used to control for the endogeneity of profits. However, weak instruments may bias downward the effect of profits on workers' wages. Results for continental Europe, although not very numerous, tend in the same direction. For example, using Swedish matched worker-firm data for 1981 and 1991, Arai (2003) reports that the elasticity of wages with respect to profits-peremployee is of the magnitude 0.01 . The existence of rent-sharing has also been examined in France and Norway by Margolis and Salvanes (2001) on the basis of linked employer-employee panel data. Considering a large number of statistical and economic explanations, the authors find that the estimated coefficient of profits is insignificant in France, while it is small but statistically different from zero in Norway.

Overall, strong evidence seems to support the claim that workers' wages depend upon the firms' ability to pay. Yet, very little is known about the relative magnitude of the pay-profit elasticity for male and female workers and the contribution of rent-sharing to the overall gender wage gap. Nevertheless, recent findings (e.g., Arai and Heyman, 2001; Fakhfakh and FitzRoy, 2002) suggest that the relationship between wages and profits is not neutral with respect to gender. For example, using a large Swedish matched employer-employee data set for 1991 and

PT $^{2}$ TPAbowd and Lemieux, 1993; Arai, 2003; Blanchflower et al., 1996; Christophides and Oswald, 1992; Fakhfakh and FizRoy, 2002; Hildreth and Oswald, 1997; Margolis and Salvanes, 2001; Teal, 1996; Van Reenen, 1996. 
1995, Nekby (2002) finds that the wage-profit elasticity is about 30 to 60 percent lower for women than for men. The author also shows that gender differences in rent-sharing account for less than 2 percent of the overall gender wage gap. Moreover, Rycx and Tojerow (2004) show that the wage-profit elasticity is not significantly different for men and women in the Belgian private sector.

As for Israel, while many studies focus on the level and sources of the gender wage gap in Israel (Semyonov and Kraus, 1983; Haberfeld and Cohen, 1998; Kraus, 2002; Dahan 2000) only a few decompose the wage gap by endowment effects, selection, and differences in prices (Neuman and Oaxaca, 2003, 2004). Nagelberg (2002) shows, on the basis of the Israel Income Survey, that the gender wage gap varies between 22 percent to 25 percent during the period of 1982-1997 and that most of it can be explained by unexplained differences in rates of return between male and female workers. Similarly, using the 1995 Israeli Census of Population and Housing, Neuman and Oaxaca (2004) suggest that the wage gap between male and female Westerners $^{3}$ reaches almost 26 percent and those differences in characteristics explain between 36 percent and 73 percent of the wage differentials.

\section{The Theoretical Framework}

Two models have become standard in the literature for the analysis of the impact of profits-peremployee on wages in a bargaining framework. These are the right-to-manage and the efficient bargaining model, so-named by Nickell and Andrews (1983) and McDonald and Solow (1981), respectively. While both models yield identical wage equations, they differ fundamentally in the way they treat employment: In the right-to-manage model, firms determine employment unilaterally, while wages are the result of a confrontation between the objectives of the firm and the objectives of the employees. In the efficient bargaining model, bargaining takes place with respect to both employment and wages. Nevertheless, they both suggest that wages are related to the firm’s ability to pay, i.e., to the firm’s profitability (Pencavel, 1991).

Choosing the right model to follow is not simple: "The empirical literature has not yet been able to find an appropriate test to distinguish between the principal models” (Booth, 1995, pp.

$\mathrm{PT}^{3}$ TPOf European or American origin; in comparison to Easterners (originating from Asian/African countries). 
141). However, while these models have different implications for unemployment and economic welfare, they generate identical wage equations. Hence, for the sake of simplicity, we have chosen to rely on the right-to-manage model. The model assumes a bargaining situation where a firm's profit function is given by:

$$
\Pi=R(L)-W L
$$

where $\Pi$ denotes profits, $R(L)$ is the revenues function, $W$ the wagebill and $L$ the employment level. Also consider a risk-neutral group of workers, not necessarily a union, which attempts to maximize the expected utility of a representative member, defined as:

$$
U=\frac{L}{N} W+\left(1-\frac{L}{N}\right) A,
$$

$N$ is the number of members in the group $(0<L \leq N)$ and $A$ the outside option $(W>A)$. The outside option is the expected value of revenues perceived by an individual in the event of redundancy. It depends positively on the unemployment benefit and on the expected wage that the worker would obtain elsewhere, and negatively on the unemployment rate.

The model is solved backwards: the profit-maximizing firm determines the employment level, given the bargained wage in the first stage of the game. The resulting deal is represented by the maximization of the generalized Nash bargain. This approach boils down to maximizing the weighted product of both parties' net gain, i.e., the difference between levels of utility in the event of an agreement and in the event of no agreement. For a firm without fixed costs, the level of utility reached when bargaining fails equals zero. Indeed, since we assume that all workers are affiliated to the group, the company will have to cease production if agreement is not reached. The fallback position of a representative member of the group is equal to $A$. Accordingly, the generalized Nash bargaining problem can be written as follows: ${ }^{4}$

$$
\begin{aligned}
& \underset{W}{\operatorname{Max}_{W}} U^{\beta} \Pi=\operatorname{Max}_{W}\left(\frac{L}{N}(W-A)\right)^{\beta}(R(L)-W L) \\
& \text { s.t. } R^{\prime}(L)=W
\end{aligned}
$$

PT $^{4}$ TPSee Nickell (1999, p. 3) for a discussion on the notation. 
In this bargaining problem, $\beta \in[0,1]$ is the relative bargaining power of the workers in the wage bargain. The first order condition of this problem is given by:

$$
W=A+\beta \frac{\Pi(L)}{L}
$$

Equation (4) suggests that wages are affected by the outside option, profits-per-employee and the relative bargaining power of the workers.

The corresponding statistical specification, which will serve as a benchmark for our empirical analysis, can be written as follows:

$$
W_{i}=\alpha+\delta A_{i}+\lambda(\Pi / L)_{j}+\varepsilon_{i},
$$

where $W_{i}$ is the natural logarithm of the gross hourly wage of individual $i(\mathrm{i}=1, \ldots, \mathrm{N}) ; A_{i}$ is a vector of the proxies for the outside option of each individual - this vector includes the logarithm of the number of months worked in the last 12 months, and the logarithm of the number of days usually worked each month; ${ }^{5}(\Pi / L)_{j}$ is the logarithm of the profits-peremployee in plant $j ;(\Pi / L)_{j}$ captures the plant's good fortune; $\alpha, \delta$, and $\lambda$ are the parameters to be estimated and $\varepsilon_{i}$ is the error term. According to bargaining theory, an increase in the outside option of a representative worker reduces wage moderation. Therefore we expect a positive sign for $\delta$. The intuition behind this is that when one works full time, the probability of changing a job declines and, therefore, wage claims increase. In contrast, a drop in the expected alternative wage mitigates envy effects and wage claims. $\lambda$ measures the relative bargaining power of the workers. The sign of the latter is expected to be positive and some theories suggest that its magnitude may be different for men and women.

Gender differences in $\lambda s$ may be attributed to two sources: First, differences in $\lambda s$ can be explained by the fact that there are more male workers than female workers in capital-intensive firms. This explanation, based on Katz and Summers' (1989) argument, implies that workers in higher capital-intensive industries have more power to extort rents during wage bargaining. Second, one might argue that gender differences in $\lambda$ s reflect differences in bargaining power between men and women; these differences can arise if men are more proficient than women at bargaining over wages (Nekby, 2002).

$\mathrm{PT}^{5} \mathrm{TP}$ The number of days usually worked was calculated as the average days in the last 12 months. 


\section{The Data}

The paper relies on a unique Worker-Establishment Database (hereafter: WED) that contains detailed information on manufacturing plants with 5 or more employees in 1995 and their employee records of characteristics and wages. The database was constructed by the Central Bureau of Statistics (CBS) and was assembled using the employee identification number and the plant identification code. The data was combined from two large-scale databases. The first is the "1995 Census of Population and Housing", long Form (the 'B' level form), which was completed by approximately 20 percent of the population in Israel. It reports the employees' characteristics, the employer attributes and earnings. The second database is the "1995 Manufacturing and Crafts Survey" (MCS), carried out by the CBS. The MCS provides rich plant-level information on the plant's ${ }^{6}$ economic performance, such as: production, materials, labor, capital stock, investment, share of exports, $R \& D$ expenditures, wage-bill, and the share of exports, as well as on other plant fixed effects, such as its location, the economic branch (grouped into 7 categories), and the plant size. ${ }^{7}$ Self-employed workers and individuals from cooperative localities ("Kibbutzim"), as well as workers of public sector plants, ${ }^{8}$ were omitted from the combined sample. The final sample, integrating both data sets, covers 21,838 individuals working for 1,580 plants; 36 percent of them are females. It is representative of all plants employing at least 5 workers within the manufacturing sector in the year 1995. This makes the WED a comprehensive database.

Table I sets the means and standard deviation - in parentheses - for selected variables. By dividing the sample between the two genders, the table enables us to determine differences between men and women workers: On average, men earn significantly higher wages than women, work a larger number of hours per month, and are employed in plants where economic profits-per-employee are higher. Men also have a lower unemployment rate than women.

$\mathrm{PT}^{6}$ TPThe Israeli manufacturing sector includes about 9,000 establishments. $\mathrm{PT}^{7}$ TPMeasured by the number of employees

${ }^{8}$ Most public sector establishments in the sample are security and defense establishments, in which wages are determined according to the "Histadrut" (the labor organization) constitution. 
Table I: Description of the Data ${ }^{9}$

\begin{tabular}{lccc}
\hline & Overall Sample & Men & Women \\
\hline Gross hourly wage $^{10}$ & 113.51 & 133.37 & 78.92 \\
Profits per capita $^{11}$ & $(129.67)$ & $(143.15)$ & $(92.37)$ \\
& 219.98 & 240.63 & 181.75 \\
Months worked $^{12}$ & $(205.39)$ & $(218.97)$ & $(169.17)$ \\
& 10.84 & 11.01 & 10.55 \\
Usual days worked $^{13}$ & $(2.67)$ & $(2.48)$ & $(2.94)$ \\
& 22.46 & 22.52 & 22.36 \\
Weekly working hours & $(2.35)$ & $(2.24)$ & $(2.53)$ \\
& 46.89 & 49.27 & 42.74 \\
Plant Size (employees) & $(10.22)$ & $(10.11)$ & $(9.04)$ \\
& 0.53 & 0.50 & 0.60 \\
Age & $(0.67)$ & $(0.63)$ & $(0.74)$ \\
Years of schooling & 37.79 & 38.88 & 35.90 \\
Gender (women) & $(11.70)$ & $(11.95)$ & $(11.00)$ \\
& 12.24 & 12.21 & 12.30 \\
Number of observations & $(3.31)$ & $(3.48)$ & $(2.99)$ \\
\hline
\end{tabular}

\section{Empirical Analysis}

In this section, we investigate how individual gross hourly wage is related to firms' profits-peremployee, and whether these results vary for men and women. We also decompose the effects of rent-sharing on the gender wage differentials, on the basis of the Oaxaca (1973) and Blinder (1973) technique, what proportions of the overall gender wage gap can be attributed to the gender differences in mean profit levels of employing firms, and to the differences between wage-profit elasticities for men and women.

Unfortunately, estimating the rent-sharing effects on earnings involves two sources of econometric problems which might bias the results: first, rent-sharing is endogenous; an increase in rent-sharing will decrease profits and simultaneously increase individual earnings,

$\mathrm{PT}^{9}$ TPStandard deviations in parentheses

$\mathrm{PT}^{10}$ TPThree months average gross nominal wage, calculated from the National Insurance Institute records. Nominal New Israeli Shekels (NIS).

$\mathrm{PT}^{11}$ TPProfits $=$ Output - changes in inventory - costs of materials and wages.

$\mathrm{PT}^{12}$ TPMonths worked in the last 12 months. Between 1 and 12.

$\mathrm{PT}^{13}$ TPDays worked in the last month. Between 1 and 23. 
leading to underestimation of the rent-sharing effect. Second, there is selection bias between employee ability and plant profits which biases the elasticity of profits-per-employee upwards: high-wage firms employ high-ability workers (Kramarz and Margolis, 1999). To eliminate the endogeneity and selection biases, our estimation strategy is as follow: First, we present a benchmark OLS estimation that controls for plants' characteristics in the covariance matrix and for individual characteristics ${ }^{14}$ (column 1, Table 3). We also control for plant size and economic branch. Second, we estimate the model using instrumental variables; by this we eliminate the potential bias in the profits-per-employee elasticity due to selectivity and endogeneity. Third, we estimate the model separately for men and women, using the Blinder (1973) and Oaxaca (1973) decomposition technique. This helps us determine what proportions of the overall gender wage gap may be attributed to the rent-sharing effect. Finally, due to potential differences in rent-sharing premia to plant size, we estimate the model separately for high-wage plants and for low-wage plants. ${ }^{15}$ Table II summarizes the different stages of our empirical analysis.

\section{Table II: Estimation Procedure}

\begin{tabular}{ll}
\hline Models & Specification \\
\hline Model 1 & $\begin{array}{l}\text { Estimation of our benchmark specification, i.e., equation (5), by OLS with White } \\
\text { (1980) heteroscedasticity consistent standard errors + correction for individual } \\
\text { characteristics, plant characteristics and economic-branch differentials. We also } \\
\text { include an interaction between the ratio of women in the plant and the wage- } \\
\text { profit elasticity. }\end{array}$ \\
Model 2 & $\begin{array}{l}\text { Model } 1 \text { estimated by TSLS. Instruments for profits include all variables } \\
\text { contained in Model 2, plus per capita total amount of goods and services } \\
\text { purchased by the plant and the proportion of women in the plant. }\end{array}$ \\
Model 3 & Models 2 estimated separately for men and women. \\
Model 4 & Models 3 estimated separately for high-wage firms and for low-wage firms. \\
\hline
\end{tabular}

$\mathrm{PT}^{14}$ TPAge, age squared, total years of schooling, average working hours for the last three months, dummy variable for new immigrant, dummy variables for continent of origin for new immigrants, religious.

$\mathrm{PT}^{15}$ TP In this paper, we define a high-wage (low-wage) plant as one in which the average wage is higher (lower) than the median average wage. 


\subsection{The Benchmark Model}

The benchmark model for our analysis estimates the logarithm of the individual gross hourly wages on the individual characteristics, the logarithms of the out-side option $\left(A_{i}\right)$ - the number of months worked during the last 12 months, the average number of days worked per month, and the plant profits-per-employee; ${ }^{16}$ we also use clustering, as suggested by Greenwald (1983) and by Moulton (1990). This is done by estimating OLS regressions with White (1980) heteroscedasticity consistent standard errors for the plants. The usage of the cluster effects resolves the potential source of bias problem that results from the simultaneous use of grouped observations - the plants - and individual data: the presence of aggregate explanatory variables in Model 1 can bias the estimated standard errors and as a result distort the significance of our coefficients. This correction transforms the covariance matrix of the errors, but leaves the point estimates and the determination coefficient unaffected. ${ }^{17}$

The omitted variable bias is another important issue that arises. According to the standard competitive model of the labor market, where the equilibrium wage is determined through marginal productivity, two agents with identical productive characteristics necessarily receive the same wages. However, compensating differences may occur between similar individuals placed in different working conditions. Indeed, the disutility undergone by one individual following the performance of a task in an unfavorable situation may lead to wage compensation. In accordance with this simple description of the wage determination process, variables reflective of the productivity of the workers and their working conditions have been added to the benchmark model. These include indicator for the level of education; the age of the individual, its square; the number of hours worked; a dummy indicator for new immigrants ${ }^{18}$; and three indicators to account for workers' religion. Moreover, in order to control for gender wage differentials we have also included a gender dummy. In line with recent labor market theories, supporting the existence of an effect of the employer's characteristics on wages, we control the size of the plant, and the potential regional wage differentials, which are well documented in the literature (e.g., Farber and Newman, 1989).

$\mathrm{PT}^{16} \mathrm{TP}$ Profits were calculated by subtracting costs of materials and the wage-bill from the output.

$\mathrm{PT}^{17}$ TPBecause of its substantial impact on the standard errors of the estimates, the correction for group effects has been applied to all other models presented in this paper.

$\mathrm{PT}^{18}$ TPIsrael enjoyed mass immigration (almost 1 million immigrants) from the former Soviet-Union in the period of 1989-1993. The dummy variable for new immigrants controls for those immigrants. 
As shown in the first column of Table III and in Appendix I, all the coefficients have the expected sign and the profits-per-employee estimated elasticity is significant at the 1 percent significance level. In the benchmark model, the estimate of $\lambda$ (i.e., the elasticity between wages and profits-per-employee) is 0.12 , which is relatively high in comparison to the recent literature from the OECD countries. ${ }^{19}$ To evaluate the impact of profits on the distribution of wages, Lester's (1952) range of pay due to rent-sharing can be calculated. This statistic estimates the fraction of the overall wage inequality that is due to the variability in profits-peremployee. It is obtained by applying the following formula:

$$
4 \hat{\lambda} \cdot \frac{\sigma(X)}{\bar{X}},
$$

where $\hat{\lambda}$ is the estimated wage-profit elasticity, $X$ measures the level of plant annual profits-per worker, and $\sigma(X)$ and $\bar{X}$ denote the standard deviation and the mean value of $X$, respectively. On the basis of this formula, it appears that variability in profits accounts for 54 percent of the variance in individual wages.

\section{Table III: Estimation results}

\begin{tabular}{lccc}
\hline Variable / Model & $(1)$ & $(2)$ & $(3)$ \\
\hline & & & \\
Intercept & 2.765 & 2.854 & 2.664 \\
& $(14.16)$ & $(15.37)$ & $(14.34)$ \\
Ln (profits per worker) & 0.119 & 0.112 & 0.143 \\
& $(5.83)$ & $(6.57)$ & $(8.85)$ \\
\%Women* Ln (profits per worker) & & -0.016 & \\
& & $(2.17)$ & 0.33 \\
Ln (months worked) & 0.351 & 0.332 & $(21.25)$ \\
& $(21.69)$ & $(21.29)$ & 0.274 \\
Ln (days worked) & 0.272 & 0.274 & $(8.14)$ \\
& $(7.75)$ & $(8.10)$ & Yes \\
Individual characteristics & Yes & Yes & 0.47 \\
Plant characteristics & No & Yes & 21,838 \\
Adjusted R & 0.45 & 0.47 & 1,580 \\
Number of observations & 21,838 & 21,838 & \\
Number of plants (groups) & 1,580 & 1,580 & 65.6 \\
\hline
\end{tabular}

Notes: Robust t statistics in parentheses. Detailed results are shown in appendix II.

$\mathrm{PT}^{19}$ TP For detailed comparison see Gartner (2005). 


\subsection{The Endogeneity of Profits}

Model 1 clearly supports the hypothesis that individual wages are significantly and positively related to the plant's ability to pay. Nevertheless, caution is required: the results might suffer from the endogeneity of profits. Indeed, by construction, wages have a negative impact on profits. However, it could be argued that rent-sharing is simply reflective of the plant wage premiums. In other words, it is possible that the positive correlation between wages and profits is generated by plant-specific shocks rather than by the division of plants' profits. For example, Krueger and Summers (1988) show that wage disparities persisted in the US among workers with apparently identical individual characteristics and working conditions, employed in different industries. Since then, similar results have been obtained for numerous industrialized countries (e.g., Goux and Maurin, 1999; Hartog et al., 1997; Rycx, 2002; Vainiomäki and Laaksonen, 1995). For this reason, the second model uses a vector of dummy variables for the economic branch, and a control variable of the size of the plant. We also add an interaction variable between the ratio of women in the plants and the elasticity of profits. As expected, we find that size variable is positive and significant at 1 percent; the dummy variables for the 1 digit economic branches are also significant. We also find that the ratio of women in the plant affects negatively the wage-profit elasticity (Model 2). In other words, as the proportion of women in the plant rises, the plant shares less of its profits with the employees. This finding supports the hypothesis that profits are endogenous.

To minimize the endogeneity problem of the wage-profit elasticity, we estimated Model 2 using the technique of instrumental variables, using the per-capita total amount of goods and services purchased by the plant and the ratio of women employed in the plant as instruments for profits. The correlation between the per capita total amount of goods and services and the profits per worker is 0.96 and with the residual is 0.21 ; this means that this indicator is a good instrumental variable for the profits. The usage of the ratio of women in the plant as another instrumental variable is due to the negative impact of women on the wage-profits elasticity, as can be seen from Table III. The underlining assumption is that differences in rent-sharing may occur because women have less bargaining power than men, or suffer from discrimination in the plant. In this matter, rent-sharing will vary due to the ratio of female workers in the plant. The 
results of the TSLS regression ${ }^{20}$ are presented in the 3rd column of Table III (detailed results are shown in Appendix I). Not surprisingly, the wage-profit elasticity increases from 0.11 to 0.14 , which confirms the downward bias of the previous estimates. ${ }^{21}$ It follows that Lester's range of pay is about 66 percent of the mean wage. Yet, one could argue that the instruments that have been used are inappropriate due to over-identification. To check this, the Sargan (1964) over-identification test was used. The corresponding test statistic is computed as $N^{*} R^{2}$, were $N$ is number of observations and $\mathrm{R}^{2}$ is the percent of variation explained in the regression of the residuals from the second-stage equation on the instruments and all exogenous variables in the model. This statistic is distributed $\chi^{2}$ with 1 degree of freedom and equals the number of over-identifying restrictions. The results of the Sargan test, presented at the bottom of column 3 in Table III, show that the over-identifying restrictions cannot be rejected at the 5 percent significance level. This suggests that the two instruments are valid and that Model 3 is well specified. Our findings suggest that after controlling for the endogeneity of profits, rent-sharing exists in Israel and that a substantial part of the dispersion in wages is due to the variability in profits.

\section{Table IV: TSLS estimation results by gender}

\begin{tabular}{|c|c|c|c|c|c|c|}
\hline \multirow[b]{2}{*}{ Variable / Model } & \multicolumn{2}{|c|}{$\begin{array}{c}\text { Model } 4 \\
\text { All plants }\end{array}$} & \multicolumn{2}{|c|}{$\begin{array}{c}\text { Model } 4 \\
\text { Low-wage plants }\end{array}$} & \multicolumn{2}{|c|}{$\begin{array}{c}\text { Model } 4 \\
\text { High-wage plants }\end{array}$} \\
\hline & Men & Women & Men & Women & Men & Women \\
\hline Ln (profits per worker) & $\begin{array}{l}0.148 \\
(8.05)\end{array}$ & $\begin{array}{l}0.130 \\
(8.53)\end{array}$ & $\begin{array}{l}0.081 \\
(3.95)\end{array}$ & $\begin{array}{l}0.051 \\
(3.03)\end{array}$ & $\begin{array}{l}0.125 \\
(6.09)\end{array}$ & $\begin{array}{l}0.112 \\
(5.69)\end{array}$ \\
\hline Individual characteristics & Yes & Yes & Yes & Yes & Yes & Yes \\
\hline Plant characteristics & Yes & Yes & Yes & Yes & Yes & Yes \\
\hline Adjusted $\mathrm{R}^{2}$ & 0.46 & 0.39 & 0.28 & 0.26 & 0.44 & 0.36 \\
\hline Number of observations & 13,871 & 7,967 & 3,289 & 3,657 & 10,582 & 4,310 \\
\hline Number of plants & 1,407 & 1,050 & 790 & 790 & 790 & 790 \\
\hline
\end{tabular}

Notes: Robust t-statistics in parentheses. Detailed results are shown in appendix II.

$\mathrm{PT}^{20}$ TP The regression was estimated using IVREG2 procedure, which cluster the sample by plant.

$\mathrm{PT}^{21}$ TPAll coefficients in the first-stage regression are jointly significant at the $5 \%$ level. Results are available from the authors upon request. 


\subsection{Gender Differences in Rent-sharing}

So far, the lack of employer-employee data did not allow econometricians to examine the existence and magnitude of rent-sharing in Israel with respect to the genders. This section analyzes the gender differences of the wage-profit elasticity and we decompose the overall gender wage gap to determine what proportion is due to rent-sharing.

\subsubsection{Wage-Profit Elasticities by Gender}

To investigate the interaction between rent-sharing and gender, Model 3 was estimated separately for men and women. The results from this analysis are reported in Table IV and in detail in Appendix II. As previously mentioned, the OLS estimates are inconsistent because of the endogeneity of profits. Therefore, we focus on the TSLS estimation. For both sexes, we find that the coefficients of the profits-per-employee are significant at the 1 percent significance level. In addition, profit effects are higher for men than for women in both OLS and TSLS estimations: the wage-profit elasticity stands at 0.13 for women and at 0.14 for men. However, from a T-test for Model 3, one cannot reject the null hypothesis that the wage-profits elasticity is equal for both genders: the t-statistic is 61.17, with probability (p-value) 1 percent. Hence, gender differences are insignificant in remuneration from plant profits. Finally, let us notice that Lester's (1952) range of pay due to rent-sharing equals 64.4 percent and 59.2 percent for men and women, respectively.

\subsubsection{Decomposition of the Gender Wage Gap}

To complete our analysis, we decomposed the overall gender wage gap according to the Oaxaca (1973) and Blinder (1973) technique. It allows us to decompose the wage gap in two parts: a part explained by the differences in observed characteristics (i.e., different endowments) and a part explained by differences in the estimated coefficients (i.e., price effect). Separating the wage-profit elasticity from the controls, one can assess what proportion of the gender wage gap is due to: (a) differences between female and male wage-profit elasticities, (b) differences by gender in the average value of plant profits-per-employee, and (c) differences by gender in all other factors, - inter-industry wage differentials, working conditions, individual, plant characteristics, and the intercepts; the difference between the intercepts is also know as the "shift effect." The Blinder-Oaxaca gender wage gap decomposition between males and females can be re-written as follows: 


$$
\bar{W}_{m}-\bar{W}_{f}=\underbrace{(\overline{\pi / L})_{f} \cdot\left(\hat{\lambda}_{m}-\hat{\lambda}_{f}\right)}_{a}+\underbrace{\left((\overline{\pi / L})_{m}-(\overline{\pi / L})_{f}\right) \cdot \hat{\lambda}_{m}}_{b}+\underbrace{\bar{X}_{f}\left(\hat{\vartheta}_{m}-\hat{\vartheta}_{f}\right)+\left(\bar{X}_{m}-\bar{X}_{f}\right) \hat{\vartheta}_{m}}_{c} .
$$

Equation 6 takes as a non-discriminatory wage structure that of men and women, respectively, where the indices $m$ and $f$ refer respectively to male and female workers, $\bar{W}$ represents the average (in logarithm) of the gross hourly wage, $(\overline{\pi / L})$ is the average value of plant profits percapita and $\bar{X}$ is a vector containing an intercept and the average values of the individual characteristics of the workers, their working conditions, the plat sectoral affiliation, the size of their plant and the level of wage bargaining therein. $\hat{\vartheta}$ and $\hat{\lambda}$ are the TSLS regression coefficients relative to $X$ and $(\pi / L)$ reported in Table IV and Appendix III.

As shown in Table $\mathrm{V}$, the overall gender wage gap, measured as the difference between mean log wages of male and female workers, stands at 28.1 percent, which means that the average female worker earns 75.5 percent of the mean male wage. ${ }^{22}$ Moreover, depending on the nondiscriminatory wage structure used, results indicate that 12.1 percent of the gap (3.4 percent points of the gap) can be explained by the wage-profits profile: 7.7 percent of the overall wage gap can be explained by the fact that male and female workers have different endowments (a), which means that on average women are employed in plants where profits-per-employee are lower; another 4.4 percent of the gap derives from the price effect - differences between wageprofit elasticities for men and women (Table V).

\section{Table V: Decomposition of the gender wage gap}

\begin{tabular}{|l|c|ccc|}
\hline \multirow{2}{*}{$\begin{array}{l}\text { Non-discriminatory } \\
\text { wage structure }\end{array}$} & Overall gap & \multicolumn{3}{|c|}{ Percentage of overall gender wage gap: } \\
\cline { 2 - 5 } & $\bar{W}_{m}-\bar{W}_{f}$ & $\begin{array}{c}\text { Profits-per-capita } \\
\text { endowments } \\
\text { (a) }\end{array}$ & $\begin{array}{c}\text { Wage-profits } \\
\text { elasticity } \\
\text { (b) }\end{array}$ & All other factors \\
\hline Male wage structure & 28.1 & 7.7 & 4.4 & (c) \\
Female wage structure & 28.1 & 8.8 & 3.3 & 87.9 \\
\hline
\end{tabular}

Source: Model 5 (appendix III), estimated separately for men and women.

PT $^{22}$ TP Neuman and Silber (1996) also found that, for professional workers in Israel, the male mean wage is higher than the female mean wage by $30-40$ percent. 
Previous studies (Nekby, 2003; Arai and Heyman, 2001; Goos and Konings, 2001; Rycx and Tojerow, 2004; Fakhfakh and FitzRoy, 2002; Martins, 2004), using European countries' data, found that the elasticity of wages for females is substantially lower than for males, and that the elasticity ranges form 0.01 to 0.26 . Our findings are significantly higher. Nevertheless, many factors can explain these differences. First, apart from Rycx and Tojerow (2004) and from Martins (2004), previous papers used lagged profits as instrumental variables for the endogeneity of profits; however, since profits are usually auto-correlated, this makes it a poor instrument. Our results are closer to those obtained by Martins (2004), who estimated the wageprofit elasticity in the Portuguese manufacturing sector. It is important to notice that the low wage-profit elasticity and low gender wage gap obtained in the previously mentioned paper is determined by the overall collective bargaining power in the country - assuming that a higher level of bargaining power leads to a lower gender wage gap. Unlike in France, Sweden, and Belgium - whereas previous papers found low wage gaps and low elasticity - the level of collective bargaining power ${ }^{23}$ in Israel and Portugal is much lower: in 1995, the percentage of trade union memberships in Israel and Portugal was 23 and 25.6 percent, respectively, while in Belgium it was 52 percent, in Germany it was 42 percent, and in Sweden it reached more than 91 percent. Moreover, the collective agreement coverage rates in the latter countries reach 8590 percent, in comparison to 43 percent in Israel.

\subsection{High-wage firms and high-wage workers}

In the previous sections we find that, on average, women earn 28 percent less than men, and that a substantial source of the gender wage gap is due to the different endowments of men and women workers (women are more likely to be employed in low-wage firms). One may argue that this is not by chance, and that women have different capabilities than man, which are unobserved to the econometrician. This can cause another source of bias - that we compare workers with different abilities. In order to overcome this problem, we separate the 1,580 plants in the sample into two groups - high-wage plants and low-wage plants- and estimate Model 4 separately for each of the two groups. In this manner we define high-wage plants if the plant average wage is above the overall average wage, and low-wage plants are those in which the

PT $^{23}$ TP“World Labor Report 1997-98: Industrial Relations, Democracy and Social Stability”, International Labor Organization (1997). The collective bargaining power is measured by the proportion of employees under collective agreements and the union level density. 
average wage is below the overall average wage. We should find more women in the low-wage plants; however within each group there should not be a problem of unobserved abilities.

The estimation results confirm that high-wage plants share more rents than the lowwage plants, and that one is more likely to find male workers in the high-wage plants: women are distributed evenly between the plants, but 75 percent of the men work in high-wage plants (Table III, columns 3 and 4). However the results are consistent with the previous results and robust: there is no significant difference in wage-profit elasticities between genders.

\section{Conclusions}

This paper investigates for the first time, on the basis of a unique combination of two largescale datasets, how rent-sharing interacts with the gender wage gap in the Israeli manufacturing private sector. Empirical findings show that individual gross hourly wages are significantly and positively related to plant profits-per-employee, even when controlling for group effects in the residuals, individual and plant characteristics, industry wage differentials, and endogeneity of the profits. Our instrumented wage-profit elasticity is of the magnitude of 0.14 for men and 0.13 for women. Regarding the overall gender wage gap (on average women earn 28 percent less than men), 12.1 percent of this can be explained by the wage-profits profile: the results show that 7.7 percent of the gap are due to different endowments - that on average women are employed in plants where profits-per-employee are lower; another 4.4 percent of the gap is explained by a price effect. To put it differently, the findings suggest that a substantial part of the gender wage gap is attributable to the segregation of women in less profitable plants. Future research concerning the magnitude of rent-sharing should rely on matched employer-employee panel data so as to control the unobserved individual characteristics of the workers. Indeed, these characteristics might modify our results if it emerged that they were not randomly distributed between plants and/or genders. Unfortunately, for now, such data do not exist. 


\section{References}

Abowd, J. and Lemieux, T. (1993), “The effects of product market competition on collective bargaining agreements: the case of foreign competition in Canada,” Quarterly Journal of Economics, Vol. 108 No. 4, pp. 983-1014.

Abowd, J., Kramarz F., and Margolis D. (1999), "High-Wage Workers and High-Wage Firms,” Econometrica, 67, pp. 251-333.

Arai, M. (2003), "Wages, profits and capital intensity: evidence from matched worker-firm data.” Journal of Labor Economics, Vol. 21 No. 3, pp. 593-618.

Arai, M. and Heyman, F. (2001), "Wages, profits and individual unemployment risk: evidence from matched worker-firm data,” FIEF Working Paper Series, No. 172.

Bayard, J.M., Hellerstein, J., Neumark, D. and Troske, K. (1999), "New evidence on sex segregation and sex difference in wages from matches employer-employee data," NBER Working Paper, No. 7003.

Becker, G. (1957), The Economics of Discrimination, University of Chicago Press, Chicago.

Blanchflower, D.G., Oswald, A.J and Sanfey, P. (1996), "Wages, profits and rent-sharing," Quarterly Journal of Economics, Vol. 111 No. 1, pp. 227-51.

Blau F. and Kahn, L. (2000), “Gender differences in pay,” Journal of Economic Perspectives, Vol. 14 No. 4, pp. 75-99.

Blinder, A. (1973), "Wage discrimination: reduced form and structural variables," Journal of Human Resources, Vol. 8 No. 4, pp. 436-65.

Booth, A. (1995), The economics of the trade union, Cambridge University Press, Cambridge. Carrington, W. and Troske, K. (1998), "Sex segregation in U.S. manufacturing," Industrial and Labor Relations Review, Vol. 51 No. 3, pp. 445-64.

Christofides, L.N. and. Oswald, A.J (1992), "Real wage determination and rent-sharing in collective bargaining agreements,” Quarterly Journal of Economics, Vol. 107 No. 3, pp. 9851002.

Cohen,Y. and Y. Haberfeld, (2003), "Gender, Ethnic, and National Earning Gaps in Israel: The Role of Rising Inequality", Mimeo, Presented at the Sapir Center workshop on earnings inequality.

Dahan, M. (2002), “The Rise of Earnings Inequality,” chapter 15 in Ben-Bassat,-Avi, ed. The Israeli economy, 1985-1998: From government intervention to market economics. Cambridge and London: MIT Press, pp. 485-517 
Denny, K. and Machin, S. (1991), “The role of profitability and industrial wages in firm level wage determination,” Fiscal Studies, Vol. 12, pp. 34-45.

Fakhfakh, F. and FitzRoy, F. (2002), "Basic wages and firm characteristics: rent-sharing in French manufacturing,” mimeo, ERMES, Université de Paris II.

Farber, R. and Newman, S. (1989), "Regional wage differentials and the special convergence of worker characteristics prices,” Review of Economics and Statistics, Vol. 71 No. 2, pp. 224-31

Fields, J. and Wolff, E. (1995), "Interindustry wage differentials and the gender wage gap," Industrial and Labor Relations Review, Vol. 49 No. 1, pp. 105-20.

Groshen, E.L. (1991), "The Structure of the female/male wage differential: is it who you are, what you do, or where you work?” Journal of Human Resources, Vol. 26 No. 3, pp. 457-72.

Hildreth, A.K.G. and A.J. Oswald (1997), "Rent-sharing and wages: evidence from company and establishment panels,” Journal of Labor Economics, Vol. 15 No. 2, pp. 318-337.

International Labor Organization (1997), “World Labor Report 1997-98: Industrial Relations, Democracy and Social stability,” Geneva.

Katz, L.F. and Summers, L.H. (1989), “Industry rents: evidence and implications,” Brooking Papers on Economic Activity, Special Issue, pp. 209-75.

Krueger, A. and Summers, L. (1988), "Efficiency wages and inter-industry wage structure," Econometrica, Vol. 56 No. 2, pp. 259-93.

Lester, R.A. (1952), “A range theory of wage differentials," Industrial and Labor Relations Review, Vol. 5 No. 4, pp. 483-500.

MacPherson, D. and Hirsch, B. (1995), "Wages and gender composition: why do women's jobs pay less?” Journal of Labor Economics, Vol. 13 No.3, pp. 426-71.

Manning, A. (1987), “An integration of trade union models in a sequential bargaining framework,” Economic Journal, Vol. 97 No. 385, pp. 121-39.

Margolis, D.N. and Salvanes, K.G. (2001), "Do firms really share rents with their workers?” CREST Working Paper, No. 2001-16.

Martins, P. S. (2004), "Rent-sharing Before and After the Wage Bill," IZA Discussion Paper No. 1376.

Martyn A., Schank T. and Upward R. (2004), "High Wage Workers and Low Wage Firms: Negative Assortative Matching or Statistical Artefact?” University of Nottingham, mimeo.

Moulton, B.R. (1990), "An illustration of a pitfall in estimating the effects of aggregate variables on micro units," Review of Economics and Statistics, Vol. 72 No. 2, pp. 334-38. 
McDonald, I. and Solow, R. (1981), "Wage bargaining and employment,” American Economic Review, Vol. 74 No. 5, pp. 896-908.

Nagelberg, o. (2002), “The Gender Wage Gap in Israel, 1982-1997,” PhD dissertation.

Nekby, L. (2002), "Gender Differences in Rent-sharing and its Implications for the Gender Wage Gap.” Working paper series 182, Trade Union Institute for Economic Research (FIEF).

Nickell, S. (1999), “Product markets and labor markets,” Labor Economics, Vol. 6 No. 1, pp. 120.

Nickell, S. J.; Vainiomaki, J. \& Wadhwani, S. (1994), ”Wages and Product Market Power.” Economica, Vol. 61, pp. 457-473.

Nickell, S. and Andrews M. (1983), “Unions, real wages and employment in Britain 1951-79," Oxford Economic Papers, Vol. 35 (supplement), pp. 183-206.

Neuman, S. and Oaxaca, R. (2004). "Wage Differentials in the 1990s in Israel: Endowments, Discrimination and Selectivity" CEPR working paper 4709.

Neuman, S. and Oaxaca, R. (2003), "Gender versus Ethnic Wage Differentials among Professionals: Evidence from Israel", Annales-d'Economie-et-de-Statistique. Special Issue 0 (71-72), pp.267-92.

Neuman, S. and Weisberg, J. (1998). "Gender Wage Differentials and Discrimination among Israeli Managers", International-Journal-of-Manpower 19(3), pp. 161-70.

Neuman, S. and Silber, J. (1996). "Wage Discrimination Across Ethnic Groups: Evidence from Israel,” Economic Inquiry XXXIV (1996), pp. 648-661.

Pencavel, J. (1991), Labor markets under trade unionism. Employment, wages and hours, Blackwell publishers, Cambridge (MA).

Oaxaca, R. (1973), “Male-female wage differentials in urban labor markets,” International Economic Review, Vol. 14, no. 3, pp. 693-709.

Rycx, F. and Tojerow, I. (2004), "Rent-sharing and the Gender Wage Gap. Evidence from Belgian Matched Employer-Employee Data,” International Journal of Manpower, Vol. 25 No. 3, pp.279-299.

Sap, J. (1993), "Bargaining power and wages. A game-theoretic model of gender differences in union wage bargaining,” Labor Economics, Vol. 1 No. 1, pp. 25-48.

Sargan, J.D. (1964), "Wages and prices in the United Kingdom: a study in econometric methodology," in Hart, P.E., Mills, G. and Whitaker, J.K. (eds) Econometric analysis for national economic planning, Butterworths, London. 
Semyonov, M. and Kraus, V. (1983), “Gender, Ethnicity and Income Inequality: The Israeli Experience,” International Journal of Comparative Sociology 24, 3-4, pp. 258-272.

Vannetelbosch, V. (1996), “Testing between alternative wage-employment bargaining models using Belgian aggregate data,” Labor Economics, Vol. 3 No. 1, pp. 43-64.

Van Reenen, J. (1996), “The creation and capture of rents: wages and innovation in a panel of U.K. companies,” Quarterly Journal of Economics, Vol. 111 No. 1, pp. 195-226.

White, H. (1980), “A heteroscedasticity-consistent covariance matrix estimator and a direct test for heteroscedasticity,” Econometrica, Vol. 48 No. 4, pp. 817-30.

\section{Appendix}

Table A-1: Earnings Equations for All Workers, Detailed Results

\begin{tabular}{|c|c|c|c|}
\hline Variable / Model & (1) & $(2)$ & (3) \\
\hline Constant & $\begin{array}{l}2.765 \\
(14.16)\end{array}$ & $\begin{array}{l}2.854 \\
(15.37)\end{array}$ & $\begin{array}{l}2.664 \\
(14.34)\end{array}$ \\
\hline Profits-per-employee (Ln) & $\begin{array}{c}0.119 \\
(5.83)\end{array}$ & $\begin{array}{c}0.112 \\
(6.57)\end{array}$ & $\begin{array}{c}0.143 \\
(8.85)\end{array}$ \\
\hline Profits-per-employee $(\mathrm{Ln}){ }^{*}$ women_ratio & & $\begin{array}{c}-0.016 \\
(2.17)\end{array}$ & \\
\hline Months worked last year (Ln) & $\begin{array}{l}0.351 \\
(21.69)\end{array}$ & $\begin{array}{l}0.332 \\
(21.29)\end{array}$ & $\begin{array}{c}0.33 \\
(21.25)\end{array}$ \\
\hline Usual days worked (Ln) & $\begin{array}{c}0.272 \\
(7.75)\end{array}$ & $\begin{array}{c}0.274 \\
(8.10)\end{array}$ & $\begin{array}{c}0.274 \\
(8.14)\end{array}$ \\
\hline Gender $($ Female $=1)$ & $\begin{array}{c}-0.362 \\
(21.93)\end{array}$ & $\begin{array}{r}-0.314 \\
(21.25)\end{array}$ & $\begin{array}{r}-0.327 \\
(23.21)\end{array}$ \\
\hline Age & $\begin{array}{l}0.066 \\
(19.53)\end{array}$ & $\begin{array}{l}0.063 \\
(19.07)\end{array}$ & $\begin{array}{l}0.063 \\
(18.90)\end{array}$ \\
\hline Age-squared & $\begin{array}{c}-0.001 \\
(15.44)\end{array}$ & $\begin{array}{c}-0.001 \\
(14.69)\end{array}$ & $\begin{array}{r}-0.001 \\
(14.44)\end{array}$ \\
\hline Education1 & $\begin{array}{c}-0.458 \\
(6.25)\end{array}$ & $\begin{array}{c}-0.423 \\
(5.91)\end{array}$ & $\begin{array}{c}-0.424 \\
(5.86)\end{array}$ \\
\hline Education2 & $\begin{array}{c}-0.274 \\
(4.20)\end{array}$ & $\begin{array}{c}-0.244 \\
(3.84)\end{array}$ & $\begin{array}{c}-0.241 \\
(3.77)\end{array}$ \\
\hline Education3 & $\begin{array}{c}-0.244 \\
(3.92)\end{array}$ & $\begin{array}{c}-0.209 \\
(3.43)\end{array}$ & $\begin{array}{c}-0.207 \\
(3.37)\end{array}$ \\
\hline Education4 & $\begin{array}{c}-0.133 \\
(2.20)\end{array}$ & $\begin{array}{c}-0.115 \\
(1.91)\end{array}$ & $\begin{array}{c}-0.113 \\
(1.88)\end{array}$ \\
\hline Education5 & $\begin{array}{c}0.005 \\
(0.08)\end{array}$ & $\begin{array}{r}0.004 \\
(0.06)\end{array}$ & $\begin{array}{r}0.004 \\
(0.06)\end{array}$ \\
\hline Education6 & $\begin{array}{c}0.121 \\
(1.99)\end{array}$ & $\begin{array}{r}0.097 \\
(1.57)\end{array}$ & $\begin{array}{r}0.095 \\
(1.54)\end{array}$ \\
\hline Education7 & $\begin{array}{c}0.369 \\
(5.93)\end{array}$ & $\begin{array}{l}0.331 \\
(5.28)\end{array}$ & $\begin{array}{c}0.326 \\
(5.19)\end{array}$ \\
\hline Education8 & $\begin{array}{c}0.348 \\
(5.47)\end{array}$ & $\begin{array}{l}0.296 \\
(4.64)\end{array}$ & $\begin{array}{c}0.289 \\
(4.51)\end{array}$ \\
\hline Education9 & $\begin{array}{c}0.553 \\
(7.02)\end{array}$ & $\begin{array}{c}0.498 \\
(6.36)\end{array}$ & $\begin{array}{c}0.489 \\
(6.26)\end{array}$ \\
\hline Working hours (Ln) & $\begin{array}{l}-0.463 \\
(16.33)\end{array}$ & $\begin{array}{r}-0.451 \\
(16.90)\end{array}$ & $\begin{array}{l}-0.45 \\
(17.02)\end{array}$ \\
\hline
\end{tabular}




\begin{tabular}{|c|c|c|c|}
\hline New immigrant (dummy) & $\begin{array}{l}-0.538 \\
(23.30)\end{array}$ & $\begin{array}{l}-0.496 \\
(25.98)\end{array}$ & $\begin{array}{l}-0.494 \\
(26.23)\end{array}$ \\
\hline $\begin{array}{l}\text { Continent of origin } \\
\text { (reference= Israeli Born) }\end{array}$ & Reference & Reference & Reference \\
\hline Asia & $\begin{array}{l}-0.057 \\
(2.55)\end{array}$ & $\begin{array}{l}-0.063 \\
(2.83)\end{array}$ & $\begin{array}{c}-0.062 \\
(2.83)\end{array}$ \\
\hline Africa & $\begin{array}{c}-0.075 \\
(4.02)\end{array}$ & $\begin{array}{c}-0.071 \\
(3.93)\end{array}$ & $\begin{array}{r}-0.07 \\
(3.90)\end{array}$ \\
\hline Europe & $\begin{array}{l}-0.127 \\
(7.73)\end{array}$ & $\begin{array}{c}-0.128 \\
(8.21)\end{array}$ & $\begin{array}{l}-0.128 \\
(8.29)\end{array}$ \\
\hline America & $\begin{array}{c}-0.016 \\
(0.55)\end{array}$ & $\begin{array}{c}-0.036 \\
(1.26)\end{array}$ & $\begin{array}{r}-0.04 \\
(1.37)\end{array}$ \\
\hline $\begin{array}{l}\text { Religious } \\
\text { (reference= Jewish) }\end{array}$ & Reference & Reference & Reference \\
\hline Muslim & $\begin{array}{c}-0.231 \\
(8.41)\end{array}$ & $\begin{array}{c}-0.164 \\
(7.03)\end{array}$ & $\begin{array}{c}-0.154 \\
(6.69)\end{array}$ \\
\hline Christian & $\begin{array}{c}-0.159 \\
(5.05)\end{array}$ & $\begin{array}{r}-0.137 \\
(4.64)\end{array}$ & $\begin{array}{c}-0.132 \\
(4.47)\end{array}$ \\
\hline Druze & $\begin{array}{c}-0.091 \\
(2.31)\end{array}$ & $\begin{array}{c}-0.056 \\
(1.61)\end{array}$ & $\begin{array}{c}-0.044 \\
(1.22)\end{array}$ \\
\hline Other religions & $\begin{array}{r}0.033 \\
(1.29)\end{array}$ & $\begin{array}{r}0.026 \\
(1.05)\end{array}$ & $\begin{array}{r}0.028 \\
(1.14)\end{array}$ \\
\hline $\begin{array}{l}\text { District } \\
\text { (reference= Jerusalem District) }\end{array}$ & Reference & Reference & Reference \\
\hline North District & $\begin{array}{c}-0.048 \\
(1.11)\end{array}$ & $\begin{array}{c}-0.041 \\
(1.09)\end{array}$ & $\begin{array}{c}-0.045 \\
(1.23)\end{array}$ \\
\hline Haifa District & $\begin{array}{r}0.085 \\
(1.69)\end{array}$ & $\begin{array}{l}0.07 \\
(1.66)\end{array}$ & $\begin{array}{l}0.07 \\
(1.65)\end{array}$ \\
\hline Central District & $\begin{array}{r}0.053 \\
(1.17)\end{array}$ & $\begin{array}{l}0.07 \\
(2.06)\end{array}$ & $\begin{array}{r}0.064 \\
(1.89)\end{array}$ \\
\hline Tel-Aviv District & $\begin{array}{l}0.109 \\
(2.45)\end{array}$ & $\begin{array}{c}0.124 \\
(3.68)\end{array}$ & $\begin{array}{l}0.121 \\
(3.58)\end{array}$ \\
\hline South District & $\begin{array}{r}-0.077 \\
(165)\end{array}$ & $\begin{array}{r}-0.061 \\
(173)\end{array}$ & $\begin{array}{c}-0.074 \\
(219)\end{array}$ \\
\hline Judea, Samaria and Gaza Areas & $\begin{array}{c}-0.175 \\
(2.94)\end{array}$ & $\begin{array}{c}-0.158 \\
(3.07)\end{array}$ & $\begin{array}{c}-0.176 \\
(3.37)\end{array}$ \\
\hline Plant Size (Ln) & & $\begin{array}{l}0.057 \\
(7.20)\end{array}$ & $\begin{array}{c}0.051 \\
(5.90)\end{array}$ \\
\hline Branch1 dummy & & $\begin{array}{c}-0.184 \\
(5.93)\end{array}$ & $\begin{array}{l}-0.18 \\
(5.83)\end{array}$ \\
\hline Branch2 dummy & & $\begin{array}{r}-0.091 \\
(3.40)\end{array}$ & $\begin{array}{c}-0.083 \\
(3.23)\end{array}$ \\
\hline Branch3 dummy & & $\begin{array}{c}0.036 \\
-1.41\end{array}$ & $\begin{array}{c}0.043 \\
-1.75\end{array}$ \\
\hline Branch4 dummy & & $\begin{array}{l}0.179 \\
(4.99)\end{array}$ & $\begin{array}{l}0.187 \\
(5.00)\end{array}$ \\
\hline Observations & 21,838 & 21,838 & 21,838 \\
\hline Number of Plants & 1,580 & 1,580 & 1,580 \\
\hline Adjusted R-squared & 0.45 & 0.47 & 0.47 \\
\hline Lester range of wage (\%) & 54.60 & 50.4 & 65.60 \\
\hline
\end{tabular}

Notes: The dependent variable is the natural log of the individual gross hourly wages. Robust t-statistics are in parentheses, using the white (1980) heteroscedasticity consistent standard errors. 
Table A-2: TLSL Earnings Equation by Gender, Detailed Results

\begin{tabular}{|c|c|c|c|c|c|c|}
\hline \multirow{2}{*}{ Variable / Model } & \multicolumn{2}{|c|}{ All plants } & \multicolumn{2}{|c|}{ Low-wage plants } & \multicolumn{2}{|c|}{ High-wage plants } \\
\hline & Men & Women & Men & Women & Men & Women \\
\hline Constant & $\begin{array}{l}2.433 \\
(11.08)\end{array}$ & $\begin{array}{l}2.922 \\
(10.73)\end{array}$ & $\begin{array}{l}3.12 \\
(8.77)\end{array}$ & $\begin{array}{l}3.891 \\
(12.15)\end{array}$ & $\begin{array}{c}2.436 \\
(9.22)\end{array}$ & $\begin{array}{c}2.594 \\
(6.91)\end{array}$ \\
\hline $\begin{array}{l}\text { Profits-per-employee } \\
\text { (Ln) }\end{array}$ & 0.148 & 0.13 & 0.081 & 0.051 & 0.125 & 0.112 \\
\hline & (8.05) & (8.53) & (3.95) & $(3.03)$ & (6.09) & $(5.69)$ \\
\hline $\begin{array}{l}\text { Months worked last year } \\
\text { (Ln) }\end{array}$ & 0.379 & 0.286 & 0.396 & 0.263 & 0.339 & 0.3 \\
\hline Usual days worked (Ln) & $\begin{array}{c}(18.27) \\
0.281 \\
(6.08)\end{array}$ & $\begin{array}{c}(13.41) \\
0.245 \\
(4.80)\end{array}$ & $\begin{array}{c}(12.12) \\
0.24 \\
(3.15)\end{array}$ & $\begin{array}{c}(10.39) \\
0.194 \\
(2.90)\end{array}$ & $\begin{array}{c}(13.40) \\
0.288 \\
(5.20)\end{array}$ & $\begin{array}{c}(8.85) \\
0.245 \\
(3.30)\end{array}$ \\
\hline Age & $\begin{array}{l}0.076 \\
(20.64)\end{array}$ & $\begin{array}{l}0.047 \\
(6.61)\end{array}$ & $\begin{array}{l}0.059 \\
(8.66)\end{array}$ & $\begin{array}{l}0.038 \\
(6.54)\end{array}$ & $\begin{array}{c}0.08 \\
(18.04)\end{array}$ & $\begin{array}{l}0.05 \\
(4.17)\end{array}$ \\
\hline Age-squared & $\begin{array}{l}-0.001 \\
(16.48)\end{array}$ & $\begin{array}{l}0.00 \\
(4.68)\end{array}$ & $\begin{array}{l}-0.001 \\
(7.40)\end{array}$ & $\begin{array}{l}0.00 \\
(5.58)\end{array}$ & $\begin{array}{l}-0.001 \\
(14.40)\end{array}$ & $\begin{array}{l}0.00 \\
(2.73)\end{array}$ \\
\hline Education1 & $\begin{array}{c}-0.417 \\
(4.71)\end{array}$ & $\begin{array}{l}-0.413 \\
(3.38)\end{array}$ & $\begin{array}{l}-0.478 \\
(3.55)\end{array}$ & $\begin{array}{l}-0.377 \\
(2.14)\end{array}$ & $\begin{array}{c}-0.391 \\
(3.92)\end{array}$ & $\begin{array}{l}-0.317 \\
(2.43)\end{array}$ \\
\hline Education2 & $\begin{array}{l}-0.246 \\
(3.04)\end{array}$ & $\begin{array}{l}-0.236 \\
(2.41)\end{array}$ & $\begin{array}{l}-0.384 \\
(3.24)\end{array}$ & $\begin{array}{c}-0.139 \\
(1.04)\end{array}$ & $\begin{array}{l}-0.198 \\
(2.14)\end{array}$ & $\begin{array}{c}-0.277 \\
(2.25)\end{array}$ \\
\hline Education3 & $\begin{array}{l}-0.198 \\
(2.52)\end{array}$ & $\begin{array}{l}-0.217 \\
(2.32)\end{array}$ & $\begin{array}{l}-0.383 \\
(3.35)\end{array}$ & $\begin{array}{c}-0.123 \\
(0.94)\end{array}$ & $\begin{array}{l}-0.134 \\
(1.49)\end{array}$ & $\begin{array}{l}-0.265 \\
(2.25)\end{array}$ \\
\hline Education 4 & $\begin{array}{l}-0.087 \\
(1.12)\end{array}$ & $\begin{array}{l}-0.172 \\
(1.88)\end{array}$ & $\begin{array}{l}-0.236 \\
(2.08)\end{array}$ & $\begin{array}{c}-0.132 \\
(1.07)\end{array}$ & $\begin{array}{l}-0.039 \\
(0.43)\end{array}$ & $\begin{array}{l}-0.162 \\
(1.39)\end{array}$ \\
\hline Education5 & $\begin{array}{l}0.013 \\
(0.17)\end{array}$ & $\begin{array}{l}-0.041 \\
(0.45)\end{array}$ & $\begin{array}{l}-0.152 \\
(1.33)\end{array}$ & $\begin{array}{c}-0.036 \\
(0.28)\end{array}$ & $\begin{array}{c}0.052 \\
(0.58)\end{array}$ & $\begin{array}{c}-0.026 \\
(0.23)\end{array}$ \\
\hline Education6 & $\begin{array}{l}0.127 \\
(1.61)\end{array}$ & $\begin{array}{l}0.006 \\
(0.06)\end{array}$ & $\begin{array}{l}-0.071 \\
(0.60)\end{array}$ & $\begin{array}{l}-0.03 \\
(0.24)\end{array}$ & $\begin{array}{l}0.179 \\
(1.98)\end{array}$ & $\begin{array}{l}0.038 \\
(0.32)\end{array}$ \\
\hline Education7 & $\begin{array}{l}0.39 \\
(4.75)\end{array}$ & $\begin{array}{c}0.174 \\
(1.84)\end{array}$ & $\begin{array}{l}0.056 \\
(0.46)\end{array}$ & $\begin{array}{l}0.013 \\
(0.10)\end{array}$ & $\begin{array}{l}0.467 \\
(4.98)\end{array}$ & $\begin{array}{l}0.257 \\
(2.18)\end{array}$ \\
\hline Education8 & $\begin{array}{l}0.369 \\
(4.58)\end{array}$ & $\begin{array}{l}0.128 \\
(1.32)\end{array}$ & $\begin{array}{l}-0.013 \\
(0.11)\end{array}$ & $\begin{array}{c}-0.016 \\
(0.13)\end{array}$ & $\begin{array}{l}0.471 \\
(5.12)\end{array}$ & $\begin{array}{l}0.239 \\
(2.00)\end{array}$ \\
\hline Education9 & $\begin{array}{l}0.512 \\
(5.56)\end{array}$ & $\begin{array}{l}0.474 \\
(3.26)\end{array}$ & $\begin{array}{c}-0.133 \\
(0.75)\end{array}$ & $\begin{array}{c}0.022 \\
(0.13)\end{array}$ & $\begin{array}{c}0.632 \\
(6.38)\end{array}$ & $\begin{array}{l}0.541 \\
(3.13)\end{array}$ \\
\hline Working hours (Ln) & $\begin{array}{l}-0.523 \\
(16.33)\end{array}$ & $\begin{array}{l}-0.405 \\
(10.45)\end{array}$ & $\begin{array}{l}-0.534 \\
(8.17)\end{array}$ & $\begin{array}{l}-0.52 \\
(9.55)\end{array}$ & $\begin{array}{l}-0.508 \\
(14.27)\end{array}$ & $\begin{array}{l}-0.333 \\
(6.96)\end{array}$ \\
\hline New immigrant & -0.583 & -0.344 & -0.343 & -0.153 & -0.594 & -0.4 \\
\hline & $(26.62)$ & $(12.26)$ & $(7.40)$ & (3.26) & $(25.48)$ & $(11.91)$ \\
\hline $\begin{array}{l}\text { Continent of origin } \\
\text { (reference= Israeli Born) }\end{array}$ & Reference & Reference & Reference & Reference & Reference & Reference \\
\hline Asia & $\begin{array}{l}-0.06 \\
(2.22)\end{array}$ & $\begin{array}{c}-0.065 \\
(1.99)\end{array}$ & $\begin{array}{c}-0.014 \\
(0.23)\end{array}$ & $\begin{array}{l}0.007 \\
(0.15)\end{array}$ & $\begin{array}{c}-0.084 \\
(2.98)\end{array}$ & $\begin{array}{c}-0.107 \\
(2.57)\end{array}$ \\
\hline Africa & $\begin{array}{c}-0.083 \\
(3.79)\end{array}$ & $\begin{array}{c}-0.048 \\
(1.72)\end{array}$ & $\begin{array}{l}-0.03 \\
(0.56)\end{array}$ & $\begin{array}{l}-0.07 \\
(1.63)\end{array}$ & $\begin{array}{l}-0.084 \\
(3.65)\end{array}$ & $\begin{array}{c}-0.032 \\
(0.96)\end{array}$ \\
\hline Europe & $\begin{array}{c}-0.112 \\
(6.14)\end{array}$ & $\begin{array}{l}-0.134 \\
(5.56)\end{array}$ & $\begin{array}{l}-0.129 \\
(2.59)\end{array}$ & $\begin{array}{l}-0.145 \\
(3.44)\end{array}$ & $\begin{array}{l}-0.11 \\
(5.93)\end{array}$ & $\begin{array}{c}-0.131 \\
(4.61)\end{array}$ \\
\hline America & $\begin{array}{l}-0.062 \\
(1.63)\end{array}$ & $\begin{array}{l}0.017 \\
(0.34)\end{array}$ & $\begin{array}{l}-0.009 \\
(0.09)\end{array}$ & $\begin{array}{c}-0.005 \\
(0.05)\end{array}$ & $\begin{array}{c}-0.075 \\
(1.86)\end{array}$ & $\begin{array}{c}-0.005 \\
(0.09)\end{array}$ \\
\hline $\begin{array}{l}\text { Religious } \\
\text { (reference= Jewish) }\end{array}$ & Reference & Reference & Reference & Reference & Reference & Reference \\
\hline Muslim & $\begin{array}{l}-0.136 \\
(4.94)\end{array}$ & $\begin{array}{c}-0.181 \\
(4.50)\end{array}$ & $\begin{array}{c}-0.061 \\
(1.11)\end{array}$ & $\begin{array}{c}-0.236 \\
(5.09)\end{array}$ & $\begin{array}{c}-0.104 \\
(3.83)\end{array}$ & $\begin{array}{c}-0.168 \\
(2.35)\end{array}$ \\
\hline Christian & $\begin{array}{l}-0.118 \\
(3.29)\end{array}$ & $\begin{array}{l}-0.134 \\
(2.69)\end{array}$ & $\begin{array}{c}-0.052 \\
(0.75)\end{array}$ & $\begin{array}{c}-0.138 \\
(2.75)\end{array}$ & $\begin{array}{c}-0.129 \\
(3.31)\end{array}$ & $\begin{array}{l}-0.084 \\
(0.74)\end{array}$ \\
\hline
\end{tabular}




\begin{tabular}{lcccccc} 
Druze & -0.027 & -0.122 & -0.045 & -0.195 & -0.061 & 0.052 \\
& $(0.56)$ & $(2.30)$ & $(0.48)$ & $(3.49)$ & $(1.27)$ & $(0.62)$ \\
Other religions & 0.038 & 0.011 & 0.103 & 0.003 & -0.015 & 0.028 \\
& $(1.10)$ & $(0.36)$ & $(1.93)$ & $(0.07)$ & $(0.34)$ & $(0.44)$ \\
District & & & & & & \\
(reference= Jerusalem & Reference & Reference & Reference & Reference & Reference & Reference \\
District) & & & & & & \\
North District & -0.03 & -0.105 & 0.137 & -0.027 & -0.043 & -0.105 \\
& $(0.74)$ & $(1.90)$ & $(1.59)$ & $(0.39)$ & $(1.11)$ & $(1.46)$ \\
Haifa District & 0.085 & 0.015 & 0.192 & -0.003 & 0.047 & 0.018 \\
& $(1.87)$ & $(0.27)$ & $(2.14)$ & $(0.05)$ & $(1.17)$ & $(0.28)$ \\
Central District & 0.09 & -0.011 & 0.191 & 0.01 & 0.06 & -0.026 \\
& $(2.53)$ & $(0.19)$ & $(2.06)$ & $(0.14)$ & $(1.85)$ & $(0.39)$ \\
Tel-Aviv District & 0.145 & 0.052 & 0.163 & 0.048 & 0.14 & 0.031 \\
& $(3.92)$ & $(0.96)$ & $(1.85)$ & $(0.71)$ & $(4.14)$ & $(0.48)$ \\
South District & -0.055 & -0.14 & 0.142 & -0.038 & -0.066 & -0.131 \\
& $(1.44)$ & $(2.57)$ & $(1.58)$ & $(0.55)$ & $(1.62)$ & $(1.91)$ \\
Judea, Samaria and Gaza & -0.142 & -0.273 & 0.156 & 0.015 & -0.235 & -0.396 \\
Areas & $(2.11)$ & $(3.21)$ & $(1.35)$ & $(0.16)$ & $(2.72)$ & $(3.60)$ \\
& 0.049 & 0.049 & 0.062 & 0.058 & 0.006 & 0.017 \\
Plant size (Ln) & $(4.82)$ & $(5.19)$ & $(5.10)$ & $(7.84)$ & $(0.47)$ & $(1.13)$ \\
Branch1 dummy & -0.158 & -0.23 & -0.121 & -0.122 & -0.105 & -0.191 \\
& $(4.16)$ & $(5.93)$ & $(2.16)$ & $(2.42)$ & $(2.44)$ & $(3.59)$ \\
Branch2 dummy & -0.055 & -0.147 & 0.089 & -0.033 & -0.083 & -0.091 \\
Branch3 dummy & $(1.78)$ & $(4.27)$ & $(1.72)$ & $(0.86)$ & $(2.51)$ & $(2.09)$ \\
& 0.054 & -0.005 & 0.109 & 0.165 & 0.02 & -0.04 \\
Branch4 dummy & $(2.14)$ & $(0.12)$ & $(2.77)$ & $(3.12)$ & $(0.70)$ & $(0.74)$ \\
& 0.167 & 0.166 & 0.165 & 0.209 & 0.127 & 0.128 \\
Observations & $(4.26)$ & $(3.92)$ & $(2.92)$ & $(4.28)$ & $(3.21)$ & $(2.59)$ \\
Number of plants & & & & & & \\
Adjusted R-squared & 13,871 & 7,967 & 3,289 & 3,657 & 10,582 & 4,310 \\
\hline Noses & 1,407 & 1,050 & 790 & 790 & 790 & 790 \\
& 0.46 & 0.39 & 0.28 & 0.26 & 0.44 & 0.36 \\
\hline
\end{tabular}

Notes: The dependent variable is the natural log of the individual gross hourly wage. Robust t-statistics are in parentheses, using the white (1980) heteroscedasticity consistent standard errors. 